\title{
鋳造部品開発におけるデジタルエンジニアリング
}

\section{Digital engineering in development of casting parts}

\section{1.はじめに}

企業の競争力のひとつに市場のニーズの变化に迅速に対応 できる製品開発力をあげることができる。これをものづくり の場で捉えると製品の設計から製作にいたる工程をスムーズ に進めることができ，かつ設計変更や日程変更に柔軟に対応 できるシステムを持つことである。しかし，現実には設計の 繰返しなどのロスを生じている。

このロスを抑えるためにたとえばコンピュータシミュレー ションにより設計段階で不具合の発生を予測し対策を施すこ とで，実際の試作の回数を減らす取組みが行われている。さ らに最近では三次元 GAD（コンピュータ支援設計： Computer Aided Design）の普及により，製品開発全般にわた り情報技術を利用した効率化が行われるようになってきて いる。たとえば製品開発期間を $50 \%$ 以上短縮した事例があ $3^{1), 2)}$ 。このような取組みをデジタルェンジニアリングと呼 び，その範囲は事例により異なるが，取組む目的は下記のこ とにある。

1）情報技術の活用により可能な限りタスク（処理）を仮 想化，自動化し開発期間を短縮する。

2）それにより生じる時間を人はより知的な業務に充てる ことで開発のレベルアップを目指す。 村田＼cjkstart雅史 *

\author{
Masafumi MURATA*
}

今回解説するデジタルエンジニアリングの全体像を模式的 に図 1 に示した。大きく2つの領域がある。三次元 CAD モ デルを中心とする設計段階のゾーンと現物を中心とするゾー

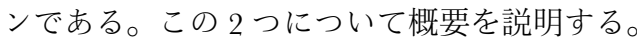

まず，最初の設計段階のゾーンであるが，ここでは三次元 $\mathrm{CAD}$ モデルを利用し， CAE（コンピュータ支援エンジニア リング： Computer Aided Engineering) や，ラピッドプロト タイピング $=\mathrm{RP}$ （迅速試作：Rapid Prototyping）により設計 品質を向上させ，また CAM（コンピュー夕支援製造： Computer Aided Manufacturing) 機能や CAT（コンピュータ 支援検査：Computer Aided Testing）機能により型製作や製 品検査に用いるデー夕を作成する。これらの業務が利用する 三次元 CAD モデルやデータは共有化されているため，設計 の変更に柔軟に対処できることが特徵である。このように製 品開発の各業務を共同で実行することをコンカレントエンジ ニアリング (CE: Concurrent Engineering) やサイマルテイニ アスエンジニアリング（SE: Simultaneous Engineering）と呼 ぶ。

一方，製作段階のゾーンでは設計段階で出力したデータに より型加工や形状検査を行う。また，デジタイザや X 線 CT （X-Ray Computed Tomography）スキャナにより現物の形状 をデジタル化しこれを設計の三次元 CAD モデルと比較する

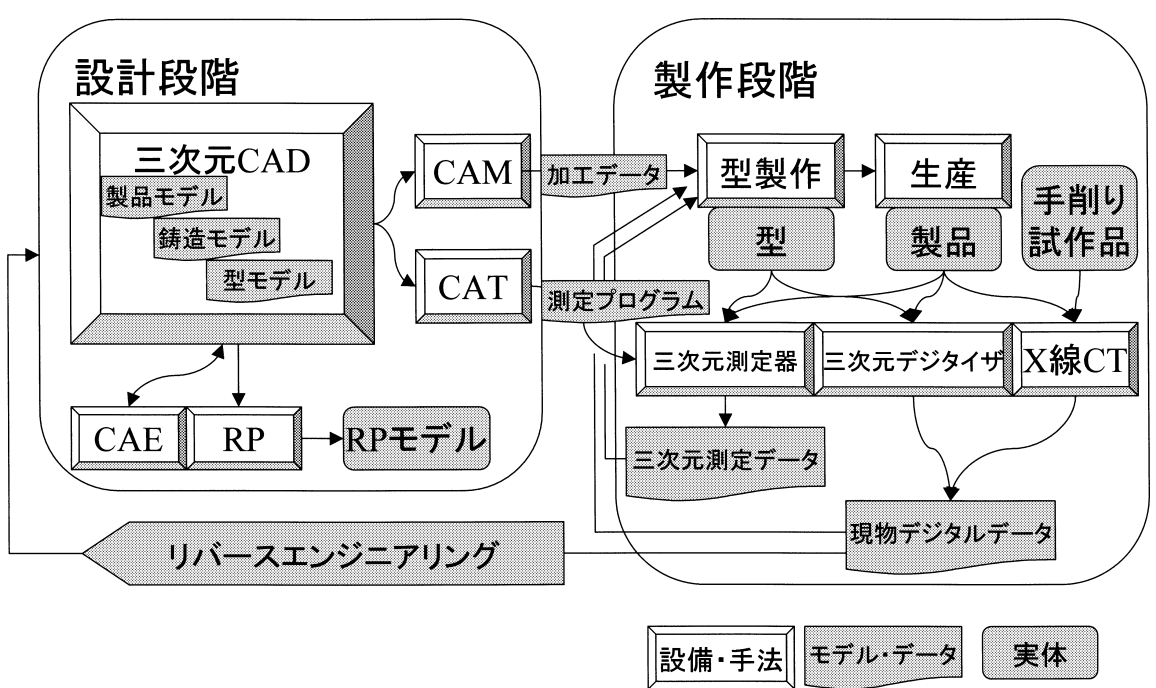

図 1 デジタルェンジニアリングの全体像

*ダイハッ工業株式会社 第一生産技術部 鋳造生技室（干 520-2593 滋賀県蒲生郡竜王町大字山之上 2910）。 Daihatsu Motor Co., Ltd. Foundry \& Machine Engineering Div. Foundry Engineering Dept. (2910 Yamanoue, Ryuo-cho, Gamo-gun, SHIGA 520-2593).

E-mail: Masafumi_Murata@mail.daihatsu.co.jp 受理日：平成 16 年 4 月 1 日 


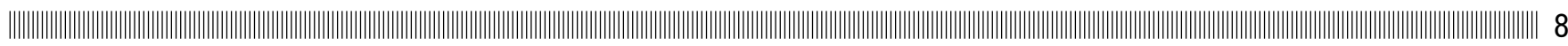

こともできる。さらにはこの現物のデジタルデータをマス ターモデルとして利用することもできる。この現物を出発点 とする流れをリバースエンジニアリング（RE）と呼んでい る。

以上デジタルェンジニアリングについて大きく分けた $2 つ$ のゾーンについて主に鋳造部品の開発を例として第 2 章と第 3 章に分けて述べることにする。

\section{2. 三次元 CAD によるデジタルエンジニアリング}

\section{1 三次元 CAD}

\subsection{1 ソリッドモデル}

デジタルェンジニアリングにおいて従来の設計図面にあた るむのが三次元 $\mathrm{CAD}$ モデルである。三次元 $\mathrm{CAD}$ モデルの形 状表現方法にはワイヤーフレームモデル, サーフェスモデル およびソリッドモデルがある。ワイヤーフレームモデルは三 次元形状を線で表現し，サーフェスモデルは面で表現してい る。そしてソリッドモデルは面で形状を表現し，かつ面のど ちら側に物体があるかの情報をもち，あいまいな部分（数学 的に矛盾しない形状）がないのが特徴である。つまり，ソ リッドモデルは鋳造品のように中身が詰まったモデルである。 また，形状にあいまいさがないため次の上うな長短所がある。

1）長所：シミュレーションモデルへの変換や，モデル同 士の干渉評価など製品開発に打ける用途が広い。

2）短所：あいまいさがないモデリングをしようとすれば, 複雑な形状を入力できない場合がある。

この長所を活かした技術がデジタルエンジニアリングには 多い。一方，その短所を解決する答えは次章で述べる X 線 CT スキャナなどによるリバースエンジニアリングがひとつ の解である。

\subsection{2 三次元 $\mathrm{CAD}$ モデルの種類}

複数の部品により構成される製品の場合各部品についてモ デルを作成していく。またひとつの鋳造部品を捉えた場合も 部品としての完成品である製品モデル，機械加工前の鋳造モ デルおよび型モデルなどいくつかの派生モデルが存在する (表 1)。

これらのモデルに加え仕様書など文書む含めて形状や寸法 などのデー夕を相互に関連付けることができる。このモデル や文書群を一元管理するシステムを PDM（Product Data Management）と呼ぶ。これはあるモデルや文書を变更した場 合，他のモデルや文書の関連する形状や寸法が自動的に変更 されるということである。しかも設計や生産技術など各部署 が離れている場合でも LAN（構内通信網： Local Area Network）経由で随時それぞれのモデルや文書を確認するこ とができる。したがって，ある部署が不都合を見つければた だちに設計変更の見直しを要求することが可能である。ただ し，そのような変更は関連するモデルに打いて矛盾しないよ うにあらかじめモデルを作成しておく必要がある。このよう な矛盾を起こさないためにそ机らのモデリングに関わる担当 者が密に情報を交換する必要がある。また, 三次元 CAD ソ フトゥエアの販売者とコンサルティング契約を締結し, 三次 元 CAD モデリングに習熟した技術者の指導を受けるのあ選 択肢のひとつである。図 2 はアルミニウムダイカスト部品
表 1 ひとつの部品開発で作成する三次元 $\mathrm{CAD}$ モデル の例

\begin{tabular}{c|c}
\hline \hline 種 類 & \multicolumn{1}{|c}{ モデルの内容 } \\
\hline 基本モデル & 機能評価に必要な最小限の形状 \\
\hline 型 モ デル & 鋳型の形状 \\
\hline 鋳造モデル & 抜き勾配, 角 R を含む鋳造後の形状 \\
\hline 製品モデル & 鋳造材を機械加工した形状 \\
\hline
\end{tabular}

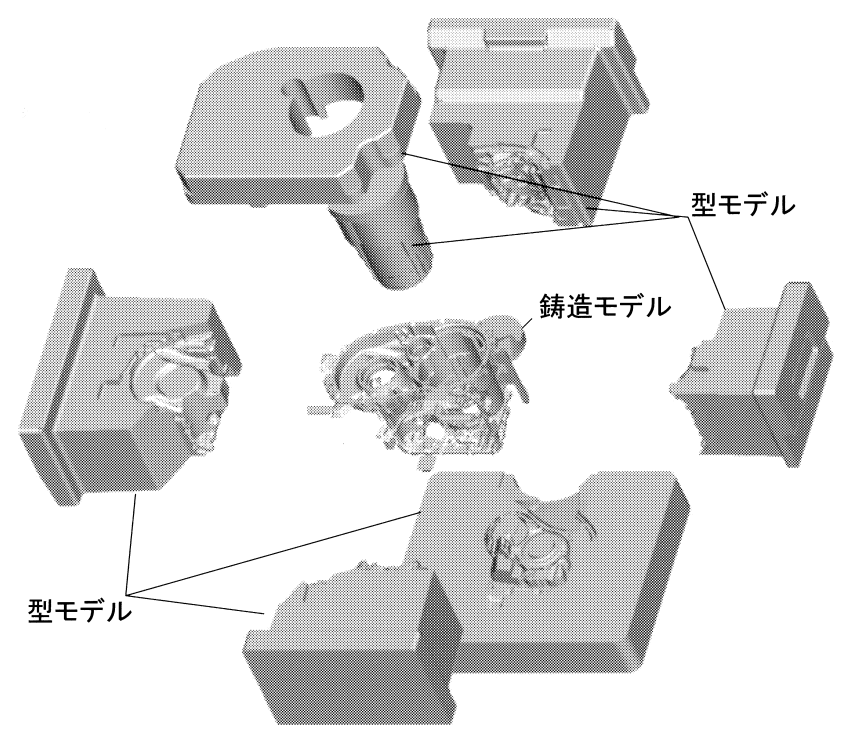

図 2 三次元 $\mathrm{CAD}$ モデルの例

表 2 三次元 CAD 用コンピュータ仕様例（2003 年）

\begin{tabular}{l|l}
\hline \hline \multicolumn{1}{c|}{ 項 目 } & \multicolumn{1}{c}{ 仕 様 } \\
\hline $\begin{array}{l}\text { OS (オペレーティング } \\
\text { システム) }\end{array}$ & Windows 2000 \\
\hline $\mathrm{GPU}$ & Xeon 2.8 GHz 2 個 \\
\hline メモリ & $2 \mathrm{~GB}$ \\
\hline グラフィックボード & $\begin{array}{l}\text { 描画能力（三角形の表示能力） } \\
6000 \text { 万トライングル 秒 }\end{array}$ \\
\hline
\end{tabular}

（ミッションケース）の金型と鋳造品の三次元 $\mathrm{CAD}$ モデルの イメージである。

2.1 .3 三次元 $\mathrm{CAD}$ システムの導入事例

本節では自動車エンジンの鋳造部品の生産準備を担当して いる筆者の所属部門における三次元 $\mathrm{CAD}$ モデル作成のため のシステムの導入事例を紹介する。

この三次元 $\mathrm{CAD}$ システムはコンピュータと三次元 $\mathrm{CAD} ソ$ フトウエアからなる。まずコンピュータはモデル化する製品 の規模や複雑さにより最適な CPU, メモリ，グラフィック ボードの搭載数量や処理能力が異なる。例として 2003 年度 


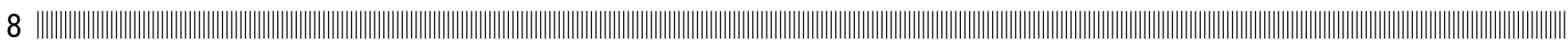

に表 2 のような仕様のコンピュータを導入している。CPUを 2 個搭載しているのは, シミュレーションを実行させながら, 報告書を作成するなどの並行作業を行いやすくするためであ る。なお，コンピュータは頻繁にモデルチェンジが行われる ため 3 年間など定期的に更新できるリース契約による導入が 選択肢のひとつである。

次に三次元 $\mathrm{CAD} ソ フ ト ゥ エ ア の$ 導入後のモデル作成方法 修得について述べる。これはまずソフトゥエア販売者による 講習を受講しソフトウエアの操作方法を学んだ後, 簡単な部 品のモデル作成を経験しながら徐々に技能を向上させている。 ひとつの製品のモデル作成ができるようになるには約 1 年を 要するが，鋳造品として製造可能な適切な抜き勾配や伸び尺 を織込んだモデルを作成できるようになるには，さらに2 3 年間の経験が必要である。

\section{1.4 三次元 $\mathrm{CAD}$ システムの運用}

三次元 $\mathrm{CAD}$ システムのコンピュータやソフトウエアの故 障修理や操作についての質問をしたり，あるいはバージョン アップを受けるにはメーカやソフトゥエア販売者と保守契約 を結ぶ必要がある。年間保守契約料は購入価格の 10 数 \%で ある。特にソフトウエアの場合はバージョンアップを行わな いと，たとえば取引先のデータのバージョンが上の場合，互 換性がない場合があるので注意が必要である。

一方，三次元 $\mathrm{CAD}$ モデルのデー夕は前述の保守契約に よって補償されないので独自に対策をしておく必要がある。 あし故意や過失によりデー夕を失えば最悪の場合企業活動が 停止に至る。このようなことを避けるためにはデータのバッ クアップが有効である。バックアップの方法には DAT や AIT などテープメディアによる方法や，本サーバのデー夕をコ ピーする第 2 のサーバを設置する方法などがある。

\section{2 コンピュータシミュレーション (CAE)}

製品開発期間を遅延させる大きな要因のひとつが機能や品 質上の不具合である。これを設計段階で見つけ出し，対策す るにはコンピュータシミュレーションの利用が有効である。 いわゆる CAE である。たとえば，鋳造の分野では凝固解析 や湯流机解析を企業が利用し成果を上げている33。 また最近 では最適化手法との組合せで複数の設計変数の組合せから最 良の条件を見つけ出す方法も行われている4)。CAO（コン ピュー夕支援最適化：Computer Aided Optimization）之呼ぶ 手法である。

以前はこのコンピュータシミュレーションのモデルを単独 で作成していたが，三次元 $\mathrm{CAD}$ モデルを利用することで効 率的に作成できるようになった。実際にはシミュレーション ソフトゥエアの自動メッシュ分割機能を利用するのであるが, その機能は STL（Standard Triangulation Language）形式のモ デルに対応している場合が多い。STL 形式は図 3 のようにモ デルの表面を大小の三角形で覆うことで近似した三次元モデ ルの表現方法である。

\subsection{1 鋳造シミュレーション事例}

図 4 はミッションケース（アルミニゥム合金ダイカスト品） の湯流れ解析の例である。矢印の部分に空気を多く巻込んだ 溶湯が集まることがわかったため，オーバーフローを設け， 空気を多く巻込んだ溶湯を逃がすようにした。

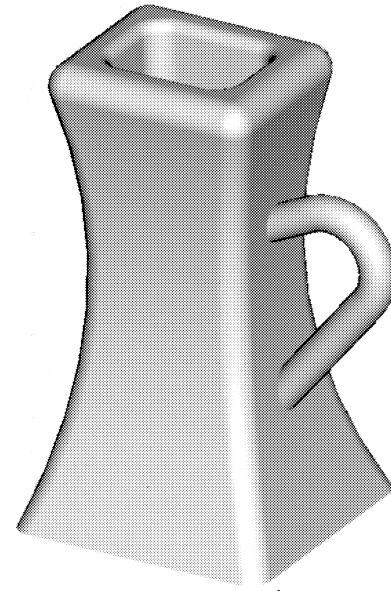

三次元CADモデル

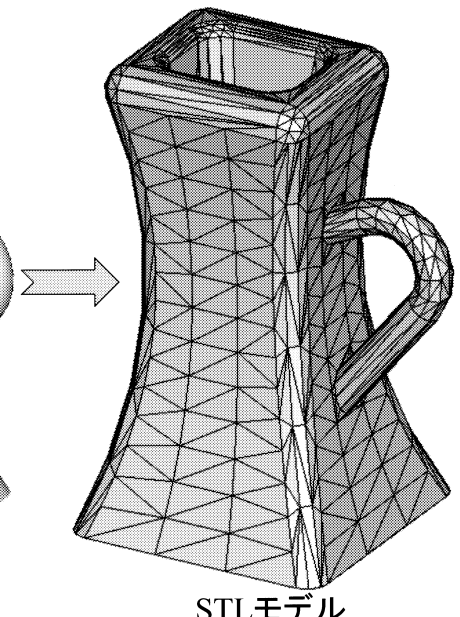

STLモデル
図 3 三次元 CAD モデルの STL の变換

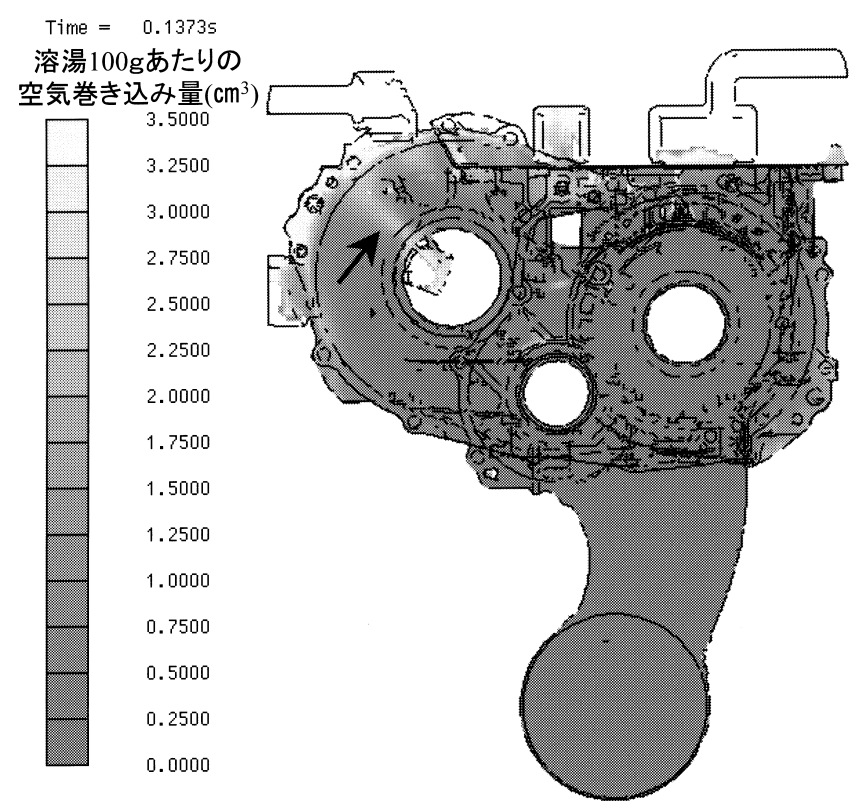

図 4 湯流れシミュレーションの例

\section{3 ラピッドプロトタイピング}

三次元 $\mathrm{CAD}$ であコンピュータの画面上でモデルの確認は 可能であるが，実体化すればより直感的に問題点を検出でき る効果がある。ラピッドプロトタイピングは三次元 CAD モ デルから短時間で同じ形状の実体を制作する方法である。そ の代表的な方式の光造型の制作工程を図 5 に示しラピッドプ ロトタイピングの原理を説明する。まず，三次元 CAD モデ ルからスライスデータ（断面形状）を十分な狭い間隔で読み 取る。そのスライスデー夕により実体のスライスを作成する。 これは光硬化性樹脂にレーザ光線をスライスデー夕に倣って 照射することで実現している。このスライスの作成を最下層 から最上層まで硬化物を載せたテーブルをスライスごとに降 下させながら行うと実体モデルが完成する。他にラピッドプ ロトタイピングの材料とスライス作成方法には粉末を焼結す る方法5), 6) やシートを切断する方法7)などがある。図 6 は ヘッドシリンダの光造型モデルである。 


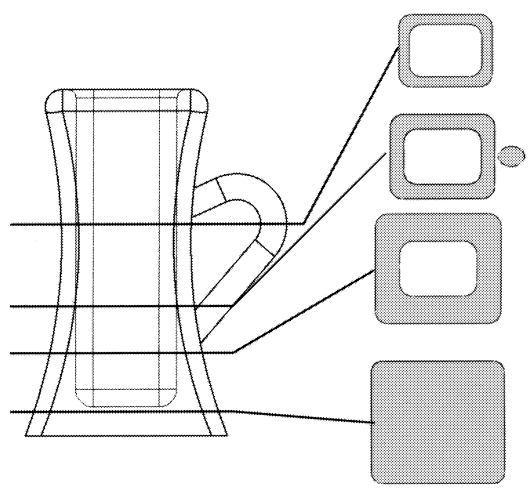

(1)スライスデータの作成

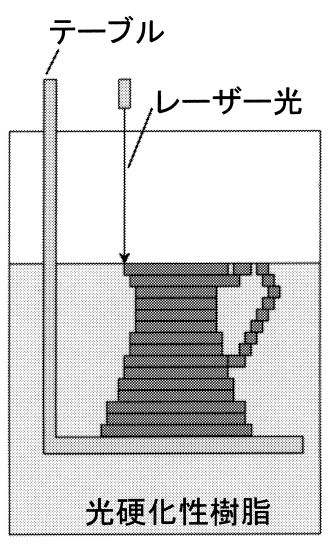

(2)n層の成形
(3)テーブル降下

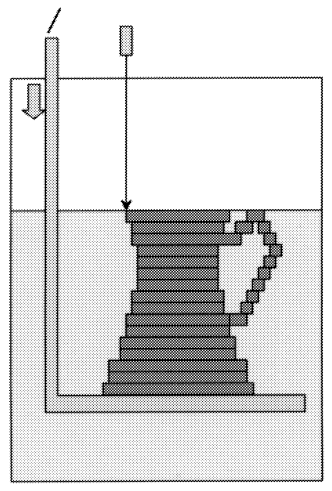

(4) $n+1$ 層の成形

図 5 ラピッドプロトタイピングの原理

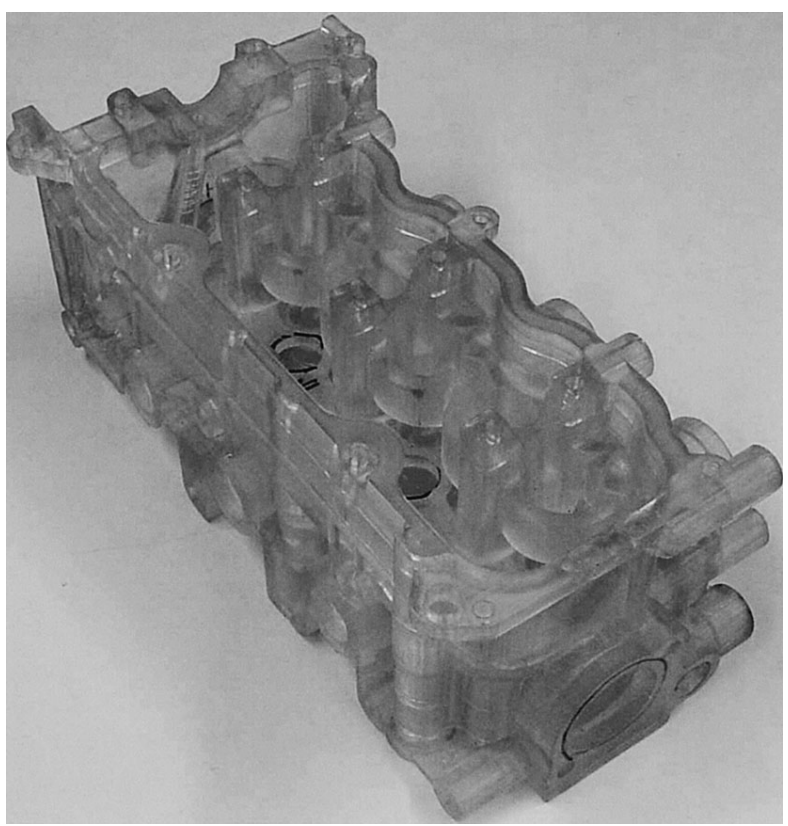

図 6 光造型モデル

\section{4 三次元モデルからの CAM データ作成}

従来二次元の製品図から型図面を設計し，これに基づいて 型加工データを作成していたが，これでは開発期間の短縮に 対処できない。さらに，製品形状が複雑になればこれを三次 元化し適切な型割りを間違いなく設計するのはますます困難 になる。

しかし，デジタルェンジニアリングでは型モデルも同時に

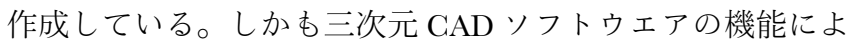
り型の割面や抜き勾配の検証も可能である。そしてその型モ デルを基に NG 加工をシミュレートし適切な加工データを出 力することができる。こうすれば，迅速に型加工に移行でき るだけでなく，設計変更にも柔軟に対応できる。

図 7 は NG加工シミュレーションのイメージである。

\section{5 三次元形状検査プログラムの作成}

実際に製品を製作するとその形状がモデル通りにできてい るかを検査することになる。三次元形状の場合, 主に三次元

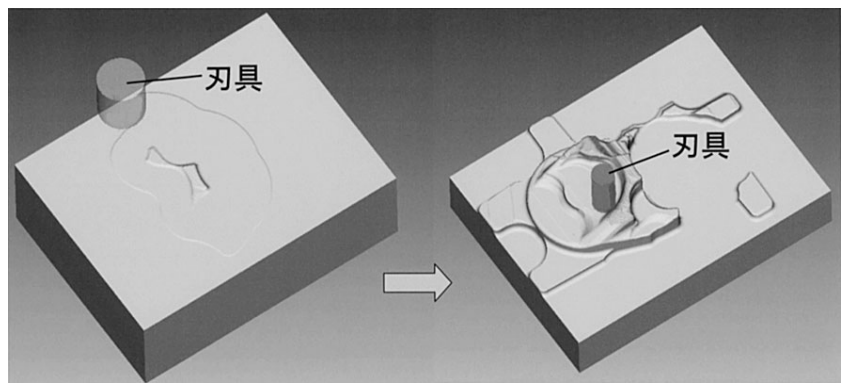

図 $7 \mathrm{NG}$ 加工シミュレーション

座標測定器（GMM: Coordinate Measuring Machine）により 測定する。三次元座標測定器はプローブと呼ぶ測定端子を物 体に接触させることで，その点の三次元的位置を測定する装 置である。物体の形状が複雑になると測定点数が増加し，ま た量産製品の場合，今後同じ測定を繰返すことになるため, 自動的に測定を行うプログラムを組んでおくことになる。そ のプログラムは，プローブが移動中に製品に干渉してはなら ないし，誤差評価のために測定点の正の座標値を記憶させて おく必要がある。従来は二次元図面を読み取ったり，現物を 測定しながらその軌跡をプログラムとして記録させるなどし ていた。しかし，デジタルェンジニアリングでは基本的に設 計を三次元化するためそれに対応できるプログラム作成方法 が必要になってくる。

この三次元座標測定プログラムを三次元 $\mathrm{CAD}$ モデル上で 作成できるのがオフラインティーチングソフトウエアである。 これは三次元モデルをコンピュータの仮想空間内で実際の測 定時のように配置し, 測定点とプローブの通過経路を入力す る。あしプローブと製品が干渉すればソフトウエアが警告す るので回避を指示する。測定点と干渉のないプローブ経路が できればプログラムをフロッピーディスクや LAN 経由など で三次元座標測定器に転送し測定を実行する。

一般的にオフラインティーチングソフトウェアは三次元座 標測定プログラムをその国際標準規格であるDMIS (Dimensional Measuring Interface Standard) で作成する。し たがって三次元座標測定器が DMIS 対応ならオフライン 


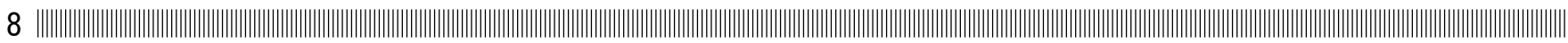

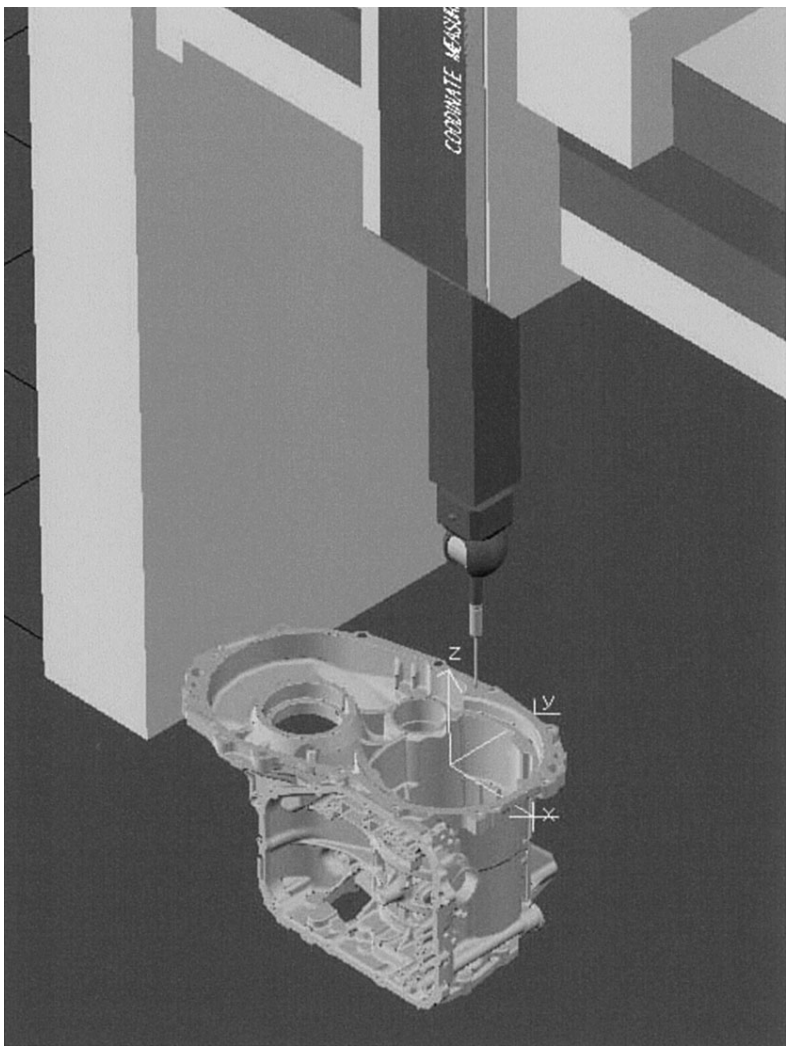

図 8 三次元測定オフラインティーチング

ティーチングソフトの利用が可能である。また三次元測定器 固有のプログラムに対応するソフトウエアあある。ただし, 三次元測定器ごとに DMIS フォーマットの細かな仕様の相違 があることがあり，その解決が必要になる場合がある。

図８はミッションケースのオフラインティーチングにおけ るプローブ動作シミュレーションのイメージである。

\section{3. 現物によるデジタルエンジニアリング}

前章では三次元 $\mathrm{CAD}$ モデルを中核として設計や生産準備 業務を効率化することを述べたが，あらゆる形状を簡単に三 次元 $\mathrm{CAD}$ モデルに入力できるわけではない。特に微妙な形 状が目的機能に影響する部品には三次元 CAD のみによるデ ジタルェンジニアリングは活用できなくなる。

このような部品をデジタルエンジニアリングを利用して開 発するには, 現物モデルの形状をデジタルデータ化すること が必要になる。しかし複雑な形状は，限られた点を測定する だけでは十分な精度で形状を表現できない。このような場合， 非接触式の三次元デジタイザ（座標読み取り機）を利用すれ ば写真機のように一度に形状デー夕を収集することができる。 収集するデー夕は形状を表現できる程度の緻密な点群であり, 各点が三次元位置情報を持つ。また後述する X 線 CT スキャ ナを利用すれば製品を破壊することなく, 内部屯含めた製品 形状を点群データとして取得することが可能である。

こうすれば従来はプロトタイプで終わっていた複雑な形状 あ繰返し再現可能な技術として三次元 CAD モデルに織込む ことが可能になる ${ }^{8)}$ 。このような製品開発の流れをリバース エンジニアリングと呼ぶ。本節では現物から三次元デジタイ

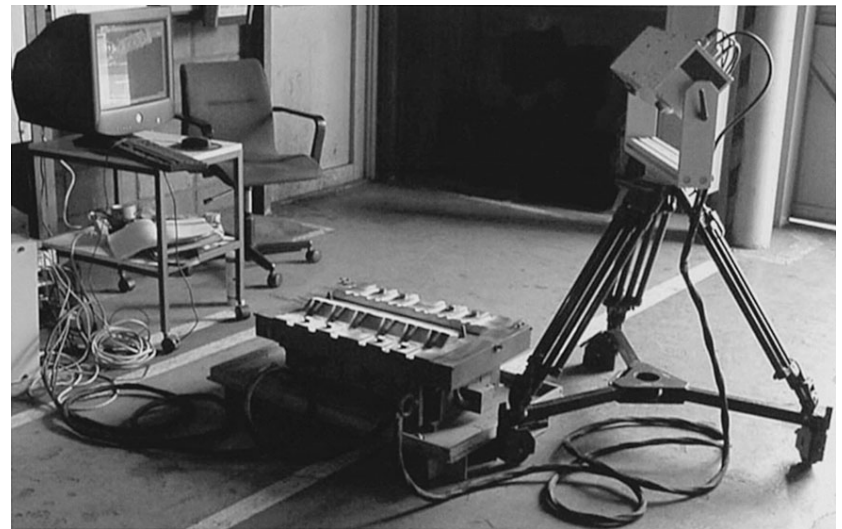

図 9 三次元デジタイザ撮影風景

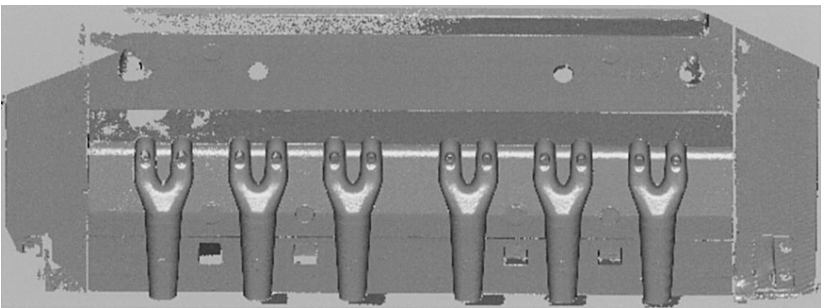

図 10 撮影デー夕

ザや X 線 CT スキャナを利用し三次元形状をデジタルデータ 化しこれを利用する技術の概要と事例を述べていくことにす る。

\section{1 三次元デジタイザ}

三次元デジタイザには接触式と非接触式があるが，ここで は短時間で複雑な形状を取込む目的から非接触式について述 べることにする。測定原理はレーザ光線を照射しその反射光 から三角測量の原理により位置を求める光学式や規則的な縞 模様の光を曲面に当てると生じるモアレ縞により評価するモ アレ法などがある ${ }^{9)}$ 。一般的に測定精度は 1 回の測定範囲が 狭いほど高くなる。測定範囲が狭い場合は複数回撮影しそれ らを貼合せて全体の形状を作る。この操作は機器に付属のソ フトウェアで可能な場合が多い。また, 取込む点群は大容量 のデータになるのでこれを扱うコンピュータは高性能なむの が必要である。

図 9 はシリンダヘッドのポート中子金型の撮影風景である。 ポート中子とはエンジンのヘッドシリンダ部の吸気または排 気経路を形づくるための鋳型の一種であり，金型に砂を充て んし焼結させることで造型している。この事例に取上げた金 型では吸気ポートと排気ポートの同一形状が各 1 組並んでお り，それらの同一性を評価することが撮影の目的である。撮 影では金型の反射むらを防止するために白色の粉末を評価面 に塗布した。なお，この粉末は撮影後にエアブローにより除 去することができる。撮影は数秒間で終わるが，一方向の場 合，陰になり撮影できない面ができるため複数の方向から撮 影し，ソフトゥエア上でそれらのデータを貼合せた。

撮影すると図 10 のような点群デー夕を得ることができる。 なお，この点群デー夕は各近傍の点同士を結び三角形を張る 


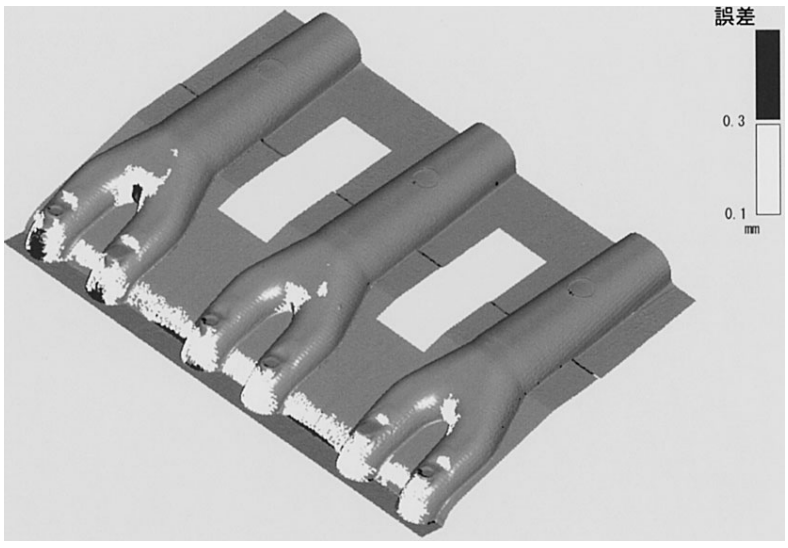

図 11 形状誤差評価結果

表 3 産業用 X 線 CT スキャナの仕様例

\begin{tabular}{c|c}
\hline \hline 項 目 & \multicolumn{1}{|c}{ 仕 様 } \\
\hline 撮影方式 & トランスレート/ローテート方式 \\
\hline $\mathrm{X}$ 線管電圧 & $450 \mathrm{kV}$ \\
\hline 撮 影 視 野 & 直径 $600 \mathrm{~mm} / 300 \mathrm{~mm} \mathrm{2} 2$ モード \\
\hline 画像解像度 & $512 \times 512 / 1012 \times 1012 \quad 2$ モード \\
\hline 画素データ & 符号付き 14 ビット \\
\hline 透 過 能力 & アルミニウム合金 $300 \mathrm{~mm}$ \\
\hline
\end{tabular}

ことでコンピュータ画面上に滑らかな面として表示できてい る。このように近傍の点同士を結び多角形を張ることをポリ ゴン化と呼んでいる。この図 10 には同じ形状が左右に並ん でおり点群評価ソフトウェア上で片方の形状を基準としもう 一方の形状を重补合せ，2つの形状の距離差を評価した結果 が図 11 である。図 11 では距離差 $0.1 \mathrm{~mm}$ 以上の領域を色分 け表示している。

\subsection{X線 CT スキャナ}

3.2.1 X 線 CT スキャナの構造と管理

$\mathrm{X}$ 線 CT スキャナは複数の方向から $\mathrm{X}$ 線を照射して得た $\mathrm{X}$ 線吸収量デー夕から断面画像を得る装置である。産業用 X 線 CT スキャナの一例（仕様を表 3 に示す）をむとに構造を説 明する。図 12 は撮影テーブルを上部から見た X 線 CT ス キャナの構造であり, 図 13 は実際の X 線 CT スキャナの撮 影テーブルを前方から見た写真である。この方式はトランス レート/ローテート方式 (TR) といい, 試料テーブルがX 線発生装置と X 線吸収量検出器の間を往復する。往復の折 り返し位置ではテーブルが回転し $180^{\circ}$ の間の多方向からの $\mathrm{X}$ 線吸収量データを検出器で得られるようにしている。そし て収集したX 線吸収量データをコンピュータ内で断面上の分 布に再構成し，画像化している。撮影時間は 1 断面あたり約 60 秒である。ただし撮影時間についてはX 線 CT スキャナ

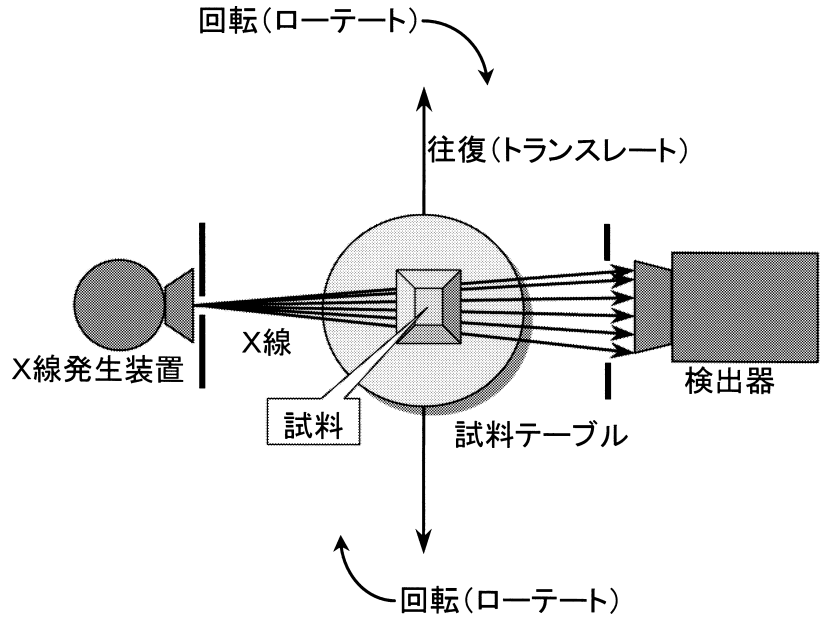

図 $12 \mathrm{X}$ 線 CT スキャナの撮影方式（TR 方式）

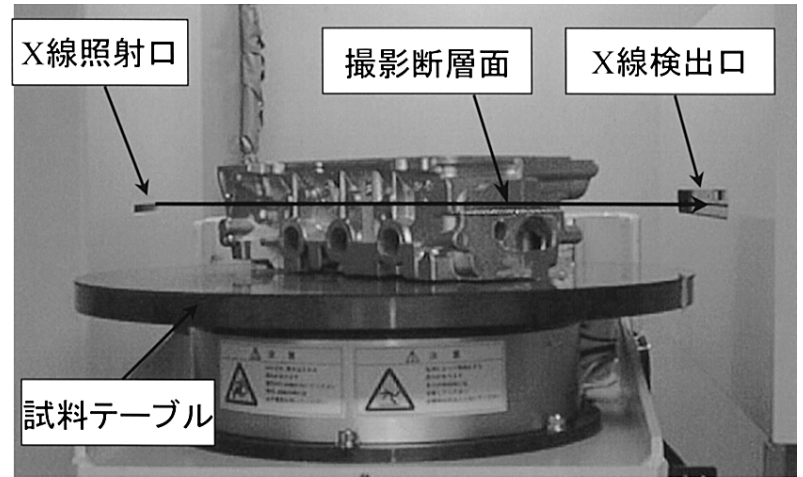

図 13 産業用 X 線 CT スキャナの内部

の撮影方式, 撮影モード（データ収集量や画像解像度など） やコンピュータ処理能力により变化する。

ところで X 線は試料の密度に比例して吸収量が増えるため 大型製品や鉄など高密度の製品を扱う場合は X 線出力の高 い装置が必要になる。たとえば X 線出力 $450 \mathrm{kV}$ の装置でア ルミニウム合金の試料を撮影する場合，鮮明な画像を得られ る肉厚は $300 \mathrm{~mm}$ 程度までである。なお，X線管出力が $1000 \mathrm{kV}$ 未満の場合 $\mathrm{X}$ 線作業主任者を選任し，それを超える 場合放射線取扱主任者の設置が法律により義務付けられてい る。事例の装置の場合は $450 \mathrm{kV}$ であるので，X線作業主任 者を選任している。

なお X 線 CT 撮影装置全体は金属製の部屋に収められてお り，規定以上の放射線が漏洩しないような対策が施されてい

\section{る(図 14)。}

さらに，作業者の放射線被曝状況を管理するため以下のこ とを実施している。

1）作業者は被曝量の記録のためフィルムバッジを携帯す る。

2）装置周辺の放射線の量を定期的に測定し記録している。

3）作業者は特殊健康診断を定期的に受診している。

以上のことは電離放射線障害防止規則（電離則）にもとづ いている。 


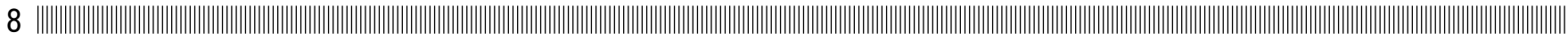

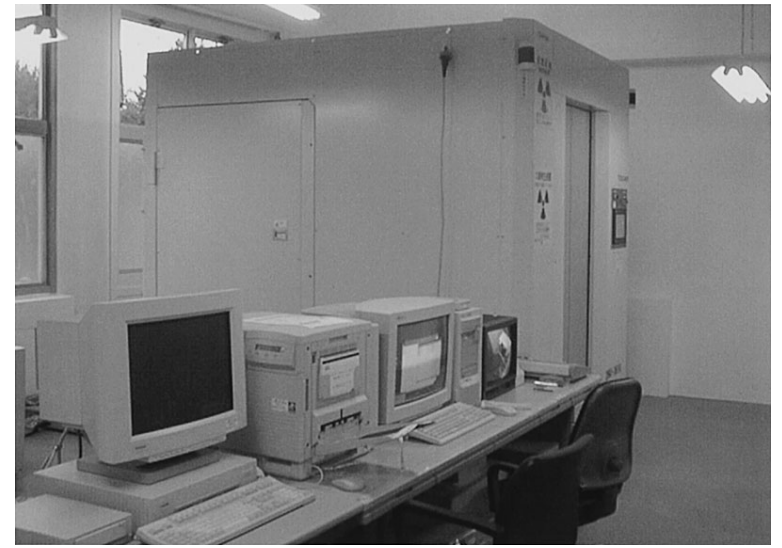

図 14 産業用 X 線 CT スキャナの外観
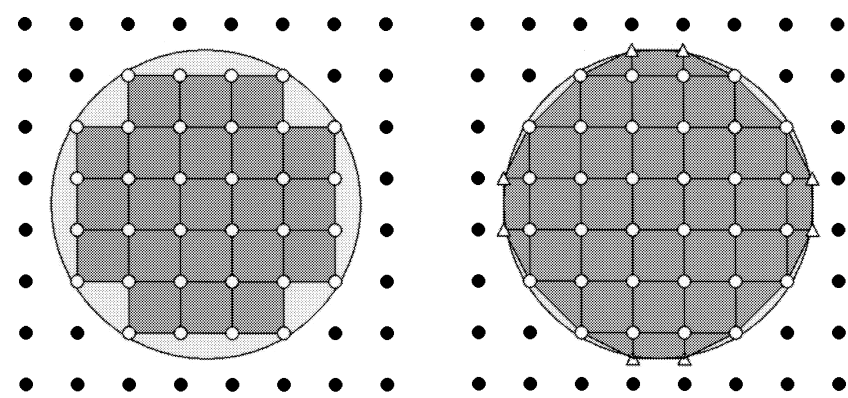

黒円:空気部の画素 白丸:材質部の画素 白三角:境界部

図 15 画像加の試料形状抽出の模式図

\subsubsection{X 線 CT 画像の用途}

これまで産業用 X 線 CT スキャナは内部欠陥検査用に開発 されてきた。しかし，X線 CT 画像は断層の密度情報であり， これを積み重ねれば三次元形状を構成することができる。 ちょうど 2.3 節で解説したラピッドプロトタイピングがスラ イスを積み重补て三次元の実体モデルを制作したのと似てい る。このため実体モデルから三次元形状を取込みシミュレー ション10) やラピッドプロトタイピングによる複製モデルの作 製 11 ) を行う事例を最近見ることができるようになった。そ して撮影速度の速いリバースエンジニアリング用途の X 線 CT スキャナの開発も行われるようになった ${ }^{12)}$ 。

次項では三次元形状を構成する方法を解説し，さらにトラ ンスミッションケースの三次元形状検査の事例を紹介する。

3.2.3 X 線 CT 画像からの三次元モデルの構成方法

ここでは X 線 CT 画像を積み重ね，物体の三次元モデルを 構成する例を述べる。

まず 1 枚の断層画像に注目するとそこに分布するピクセル

（Pixel，画素）の值は撮影面の密度分布に対応している。

適切な閾值を指定すれば試料形状の輪郭を点として抽出す ることができる。例として円筒形の試料を $8 \times 8$ ピクセルの解 像度で撮影する場合を考える。この場合 64 個のピクセルは ある閾值を境に空間部（図 15 中黒丸）と材質部（図 15 中白 丸）に分けることができる。ここで材質部のピクセルを結び 正方形の集合として試料の断面形状を表現できるようになる。 この場合解像度を高くすると，より実際の形状に近づけるこ とができる。さらに右図のように境界部のピクセル間でそれ

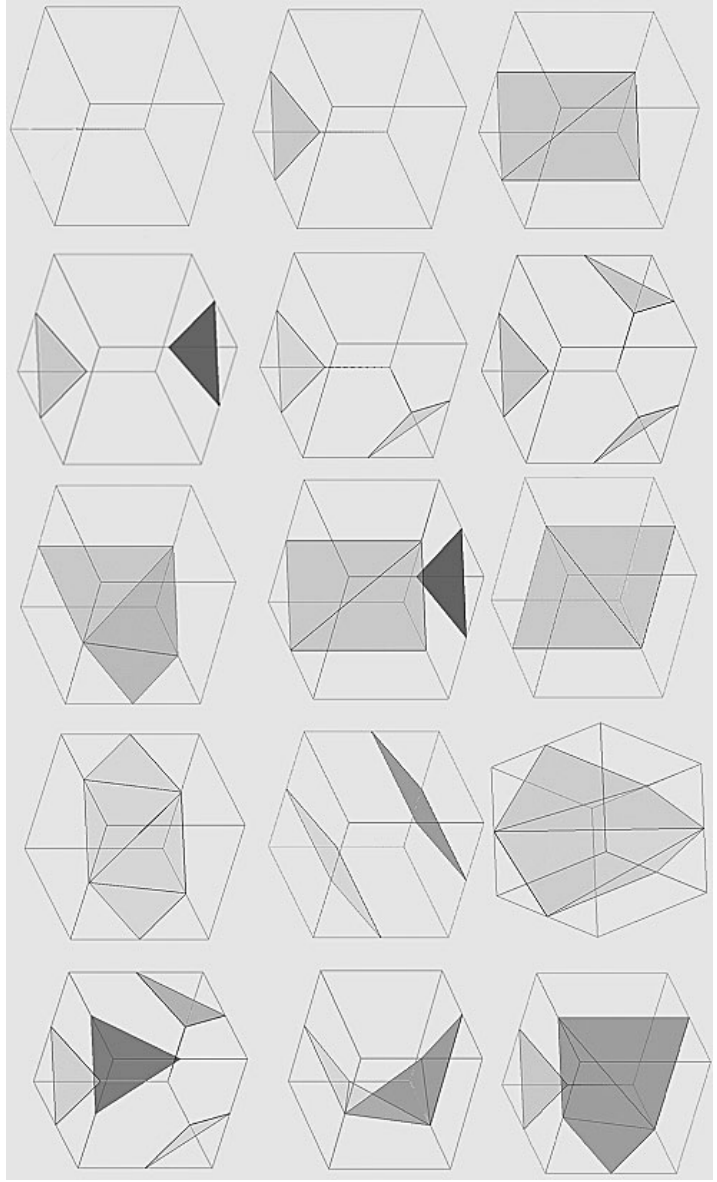

図 16 マーチンキューブ法のパターン

らの值から線形補間でちょうど閾值にあたる位置を求め（図 15 の右図三角マーク)，それらを利用して境界部の形状を埋 めていくと，さらに実際の形状に近づけることができる。

次に断層画像を撮影面之垂直な方向に積み重ねていく場合 を考える。この場合前述のピクセルが縦方向にあ並ぶことに なる。そして近傍の 8 つのピクセルを頂点とする直方体の領 域を考えることにしこれをセルと呼ぶことにする。このセル の場合もピクセル位置の值から二次元の場合のように線形補 間を利用して閾值にあたる位置を求めれば試料の三次元形状 を点群として構成できる。

さらに隣接する点群を三角形でつなげばポリゴンデー夕に することができる。三角形の張り方は，1つのセルで見た場 合閾值の分布パターンは対称なものをひとつとした場合図 16 に示す 15 のパターンのいずれかになるので，それぞれの例 に倣って三角形を張ればよい。これをマーチンキューブ法と 呼 $3 \mathbf{i}^{13)}$ 。

\subsection{4 形状評価事例}

トランスミッションケースの形状評価事例を紹介する。

撮影した断層画像は直径 $300 \mathrm{~mm}$ の視野を横 512 画素, 縦 512 画素の正方形画像に再構成したものであり，これを断層 と垂直な方向に $1 \mathrm{~mm}$ 間隔で 200 枚撮影している。したがっ てひとつのセルは X 軸， $\mathrm{Y}$ 軸は $0.586 \mathrm{~mm}$ 間隔， $\mathrm{Z}$ 軸は $1 \mathrm{~mm}$ 間隔となる。輪郭の閾值を 0 としてポリゴンデータを作成し た（図 17）。 


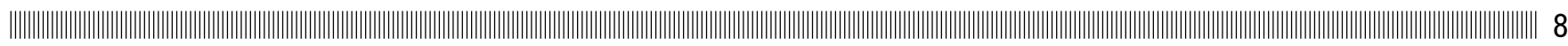

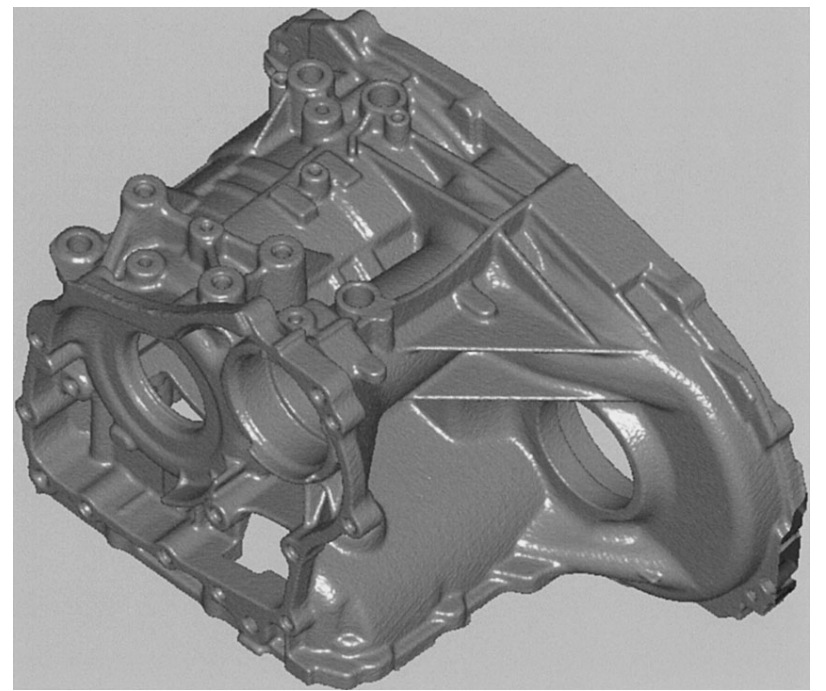

図 17 ポリゴンモデル

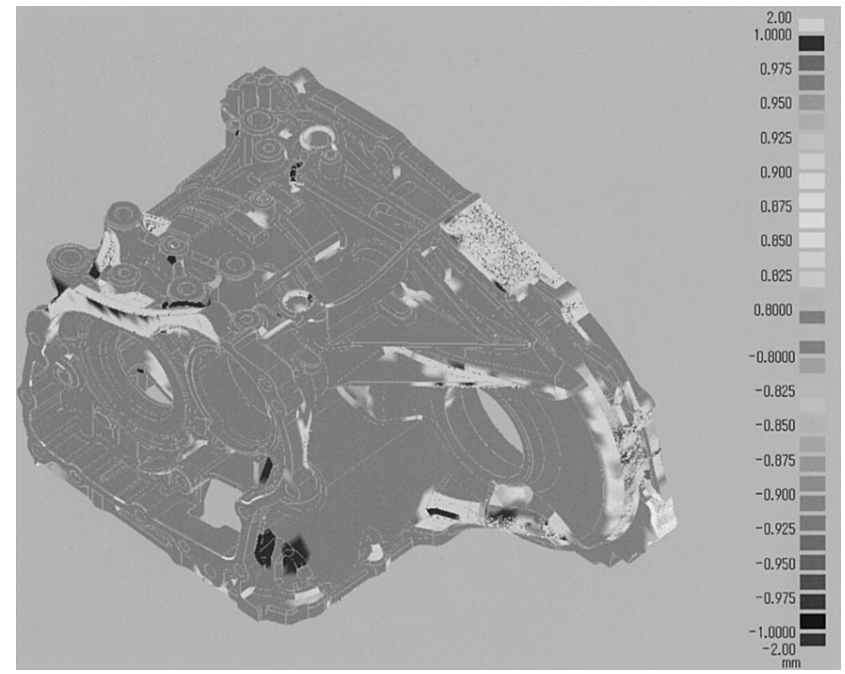

図 18 形状誤差評価結果

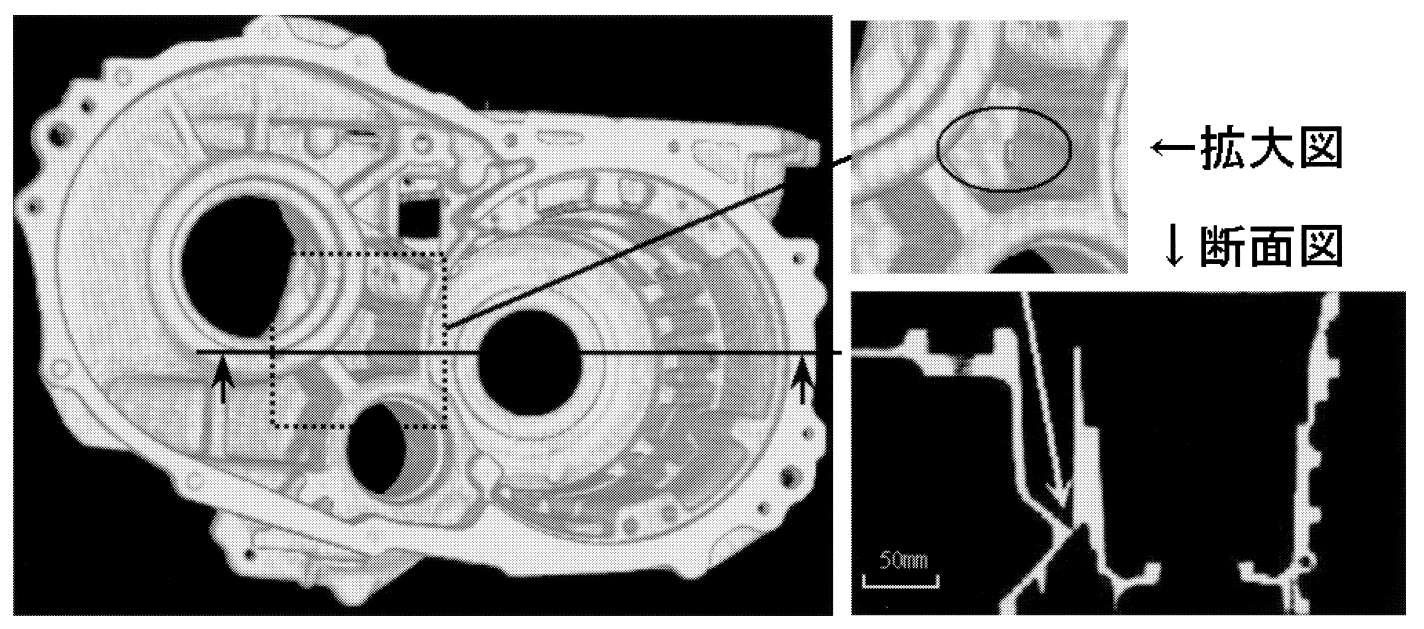

図 19 肉厚評価事例

正規のモデルである三次元 $\mathrm{CAD}$ モデルとポリゴンデータ を点群処理ソフトウエアに取込み両者の位置関係を合せた。 具体的には次の 6 点で合せた。平面を決定する 3 つの基準点 と軸を決定する 2 つ基準点と原点を決定する 1 つの基準点 である。位置合せ方法は他にも両者の誤差が平均的に最小に なる配置を自動的に求めるべストフィットなどがある。図 18 が誤差評価算結果である。なおいくつかの事例の評価結果に ついて接触式の三次元座標測定器の結果と比較したところ概 ね \pm 0.1 以内の差であった。

\section{2 .5 肉厚検査事例}

X 線 CT 画像により撮影され構成した三次元モデルから肉 厚を評価することもできる。図 19 はミッションケースの事 例である。矢印で示した箇所が基準に対し薄い肉と判定され た。図に切断画像を加えたが, 実際に肉薄であることがわか る。従来はこのような深い場所は製品を切断し, 測定してい たが，時間がかかりまたすべての肉厚を評価することは困難 であったし，また不慣れな検査担当者では見逃す可能性む あった。しかし，このように自動化できれば，評価時間の短
縮だけでなく，判定基準を適切に設定することで人による検 出能力の差を押さえ込むことができる。

3.2.6 シミュレーションモデルへの利用事例

図 20 は三次元 $\mathrm{CAD}$ モデルがない旧式のシリンダヘッドに ついて，X線 CT スキャナによる三次元モデルを利用してシ ミュレーション（凝固解析）を行った事例である。図の左が 鋳造品, 中が STL モデルそして右が凝固時間分布である。こ の場合三次元 $\mathrm{CAD}$ にりモデルを作成すると最短でも 1 週 間必要であった。しかし，X線 CT スキャナを利用すること で 2 日間のうちにシミュレーション結果を出力することがで きた。

3.2.7 X 線 CT スキャナによるポリゴンモデル利用の注意 点

現物のデジタルデータの利用において最も困るのがデータ の容量が大きなために処理に時間がかかることである。ミッ ションケースではモデル全体の三角形は 293 万枚に達する。 同じ部品を三次元 $\mathrm{CAD}$ モデルから STL 変換したものが 29 万 3 千枚であるから 10 倍である。三次元 $\mathrm{CAD}$ の場合は形状 


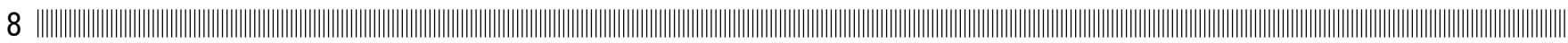

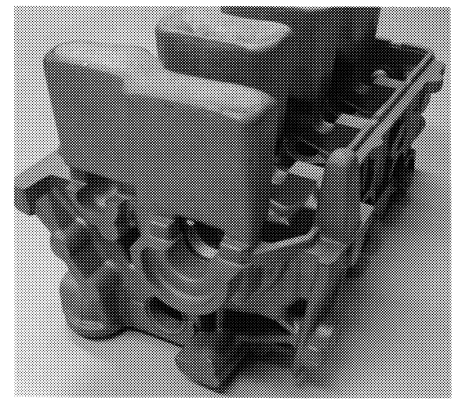

鋳造品
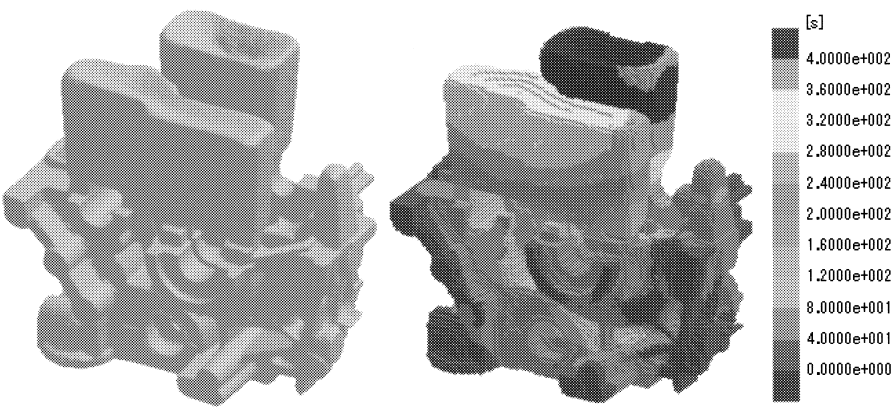

ポリゴンモデルシミュレーション結果

図 20 シミュレーション事例

の複雑さに応じてソフトゥエアが三角形の大きさを調整する からである。筆者の部門に打いても，事例に取上げたミッ ションケースの処理があまりにも遅いためコンピュータのメ モリを1GBから2GBに増やしている。したがって，このよ うな膨大な点群デー夕を処理するシステムを導入する際には 実際に扱う部品や試料による事前検証が必要である。

\section{4. おわりに}

デジタルエンジニアリングについて鋳造部品開発の事例を まじえてその内容を大まかに紹介した。ひとつは三次元 CAD モデルを中核として業務の効率化を目指す流れであり，あう ひとつはこれとは逆の現物をもとに設計を構築あるいは修正 するリバースエンジニアリングである。現在のデジタルェン ジニアリングの主流は三次元 $\mathrm{CAD}$ を中心とした流れである。 しかし，市場のニーズに応えようとすれば様々な形状を扱う 必要があり，まだ完全ではない三次元 CAD の形状表現能力 を補完する技術が必要になる。それにふさわしいのがリバー スエンジニアリング技術である。ただ，非接触デジタイザや $\mathrm{X}$ 線 CT スキャナといった設備は高価であり，また膨大な データをストレスなく処理するには上級のコンピュータが必 要である。したがってリバースエンジニアリングはまだ普及 レベルとはいえない。このため，現在のデジタルエンジニア
リングは，技術の不完全さ，コストや処理能力に課題があり， 製品開発のすべてに適用できるには至っていない。しかしな がらシステムの枠組みはできていることから，あとは各技術 の完成度向上が必要になってくると考える。この解説がきっ かけとなりデジタルエンジニアリングへの関心が増え，それ ぞれの技術の完成度が向上するようなことになれば幸いであ る。

\section{参 考 文 献}

1）新井功一, 飯島良治 : 鋳造工学, 74 (2002), 533.

2）安達範久：最近の IT 革新を鋳造業に活かす（技術講習会テキ スト), 鋳造工学会 (2001), 21.

3）吉田 勝：日経デジタルェンジニアリング， 56 (2002), 98.

4）吉田 勝：日経デジタルエンジニアリング，60（2002）， 36.

5）早野誠治：鋳造工学, 75 (2002), 853.

6）前田寿彦：鋳造工学, 75 (2002), 853.

7）黑崎徹平：鋳造工学, 75 (2002), 846.

8）粟津義雅：非破壊検査，50（2001）， 714.

9）宮原俊介：日経デジタルエンジニアリング，4（1998），187.

10）村田雅史：非破壊検查，50（2001），711.

11）坂下勝則：非破壊検査，50（2001）， 704.

12）藤井正司：非破壊検查，50（2001），698.

13）周藤安造：医学における三次元画像処理, コロナ社, (1995), 76 